\title{
Feeding strategies and resource partitioning mitigate the effects of oligotrophy for marine cave mysids
}

\author{
Pierre-Alexandre Rastorgueff ${ }^{1, *}$, Mireille Harmelin-Vivien ${ }^{1}$, Pierre Richard ${ }^{2}$, \\ Pierre Chevaldonné ${ }^{1}$ \\ ${ }^{1}$ Diversité Evolution et Ecologie Fonctionnelle Marine, ‘DIMAR', UMR-CNRS 6540, Centre d'Océanologie de Marseille, \\ Université de la Méditerranée, Station Marine d'Endoume, rue de la Batterie des Lions, 13007 Marseille, France \\ ${ }^{2}$ Littoral, Environnement et Sociétés, 'LIENSs', UMR-CNRS 6250, Université de La Rochelle, 2 rue Olympe de Gouges, \\ 17000 La Rochelle, France
}

\begin{abstract}
We investigated how large populations of several mysid species can coexist in oligotrophic underwater marine caves and their relationships in the marine cave food web using carbon and nitrogen stable isotopes. Isotopic signatures indicate food partitioning among the 5 species of cave-dwelling mysids from the northwest Mediterranean Sea we studied. Hemimysis speluncola feeds mainly on phytoplankton and zooplankton from outside the caves, Siriella gracilipes on sedimentary organic matter and zooplankton from outside, Harmelinella mariannae on small cave-dwelling crustaceans, and Hemimysis margalefi and Hemimysis lamornae mediterranea on sedimentary particulate organic matter. These differences in diet could promote coexistence of such diverse and abundant mysid faunas in marine caves by reducing interspecific competition for scarce resources. The analysis of both seston and cave sediments revealed that the quantity and quality of organic matter are strongly reduced in marine caves, suggesting that cavedwelling mysids find most of their food elsewhere. This inference agrees with documented distributions of some of these mysids outside of caves at night where they can feed in the rich littoral zone. These migrations of some species make cave-dwelling mysids important vectors of organic matter transfer from the outside euphotic littoral zone to various locations inside caves. Outside organic matter is then made available to other cave dwellers through mysid fecal pellet production and predation, as suggested by the isotopic compositions of predators like teleost fishes, decapod crustaceans, and carnivorous cladorhizid sponges.
\end{abstract}

KEY WORDS: Trophic ecology $\cdot$ Resource partitioning $\cdot$ Mysidacea $\cdot$ Marine caves $\cdot$ Oligotrophy Stable isotopes $\cdot$ NW Mediterranean

Resale or republication not permitted without written consent of the publisher

\section{INTRODUCTION}

Mediterranean rocky coasts are characterized by the presence of many cavities ranging from small crevices to large underwater caves. Two major environmental factors, light and hydrodynamics, experience drastic changes in caves, leading to spectacular changes in species assemblages (Harmelin et al. 1985). Light intensity decreases sharply inside shal- low-water caves, typically being similar at $50 \mathrm{~m}$ from the entrance to $400 \mathrm{~m}$ depth in open water (Passelaigue 1989). Total darkness prevails at the end of some cavities, depending on their architecture. Water movements are also strongly reduced inside caves, with a water residence time ranging from $1 \mathrm{~d}$ at the entrance to $>8 \mathrm{~d}$ in the innermost parts (Fichez 1991c). In the entrance of caves, benthic coverage (epibionts included) is $\geq 100 \%$, mainly composed of 
erect species, gradually disappearing and replaced by a sponge-dominated community sharing the substrate mostly with cnidarians and bryozoans (Harmelin et al. 1985, Harmelin 1994). Mobile taxa are well represented there (Harmelin 1994, Bussotti \& Guidetti 2009). Far inside the caves, extreme environmental conditions prevail, leading to marked oligotrophy (Fichez 1990). Food and propagule fluxes are limited, and sessile biomass is severely depleted (Palau et al. 1991). Benthic coverage decreases (10 to $40 \%$ ), and sessile assemblages change, displaying different species composition (Harmelin et al. 1985). Mobile taxa also change and become scarce, but several species can move over the entire range from cave entrance to cave end. These faunal changes essentially result from selective processes based on the abilities of cave dwellers to cope with the scarcity of trophic resources. Passive filter feeders and sessile carnivores are disadvantaged by the low input of organic matter (Fichez 1990, 1991c). Nevertheless, populations of carnivorous sessile species (i.e. cerianthid anemones, cladorhizid sponges) or cavedwelling fishes can be locally abundant, sometimes due to the presence of abundant swarms of mysid crustaceans (Harmelin et al. 1985).

Cave-dwelling mysids (Order Mysida) have been extensively studied recently because of their ecological relevance. In Mediterranean caves, mysids can form dense swarms of more than 10 million individuals in a single cave (Passelaigue \& Bourdillon 1986, Coma et al. 1997). Most often these mysids belong to one or several species of the genus Hemimysis, but several other species can also be encountered belonging to the genera Siriella and Harmelinella (Ledoyer 1989). In addition to their role as witnesses of large-scale environmental changes in poorly resilient ecosystems (Chevaldonné \& Lejeusne 2003), they constitute an important model to study habitat coupling through their migration patterns and fecal pellet production (Carola et al. 1993, Coma et al. 1997, Jumars 2007). Open-water mysids indeed often display circadian migrations, rising near the sea surface at night and returning to deeper layers at dawn to avoid visual predators (Mauchline 1980, Boscarino et al. 2009). Underwater caves also play the role of a shelter for cave-dwelling mysids. At night, predation pressure from visual predators, particularly fish, is reduced, and some species display horizontal migrations outside the cave (MacquartMoulin \& Passelaigue 1982, Passelaigue \& Bourdillon 1986). Coma et al. (1997) have shown how cave oligotrophy can be tempered by mysid populations through fecal pellet production.
The present study was conducted to investigate how these abundant and diverse mysid populations can occur, and co-occur, in such oligotrophic environments as marine caves. We focused our study on the most commonly found species of cave-dwelling mysids of the northwestern (NW) Mediterranean Sea. Two species are stygophilic (spend their whole lives in caves but can be found elsewhere): Hemimysis speluncola Ledoyer, 1963 and Hemimysis margalefi Alcaraz, Riera \& Gili, 1986. Two species are sciaphilic (found in various habitats not directly exposed to light) but are commonly found at cave entrances: Hemimysis lamornae mediterranea Bacescu, 1936 and Siriella gracilipes Nouvel, 1942. One species appears stygobitic (obligate to caves): Harmelinella mariannae Ledoyer, 1989. Exploring the feeding habits of these small animals by gut content analysis is difficult. We therefore analyzed their carbon and nitrogen stable isotope compositions to obtain a preliminary idea of their trophic relationships. We also analyzed the stable isotope ratios of the potential food sources and the main other cavedwellers believed to interact with mysids. This is the first time a general description of the trophic relationships among underwater cave mysids has been provided.

\section{MATERIALS AND METHODS}

\section{Sampling}

The present study focused on 2 large underwater caves located on the French Mediterranean coast near Marseille, hereafter named Jarre Cave and 3PP Cave (Fig. 1). These 2 caves are both about $120 \mathrm{~m}$ long but present contrasted topographies. The Jarre Cave $\left(43^{\circ} 11^{\prime} \mathrm{N}, 05^{\circ} 21^{\prime} \mathrm{E}\right)$ starts at $15 \mathrm{~m}$ depth and presents an almost horizontal profile from the entrance inwards, allowing some degree of water homogenization with the outside (Passelaigue 1989). The 3PP Cave $\left(43^{\circ} 09^{\prime} \mathrm{N}, 05^{\circ} 36^{\prime} \mathrm{E}\right)$ presents a descending profile from 15 to $25 \mathrm{~m}$ depth, allowing year-round cold-water trapping (Harmelin 1997). As some mysid species were not abundant enough in these 2 caves, sampling was occasionally extended to the smaller Degaby Cave $\left(43^{\circ} 16^{\prime} \mathrm{N}, 05^{\circ} 20^{\prime} \mathrm{E}\right)$ for comparative purposes (see Table 1).

Sampling was performed to obtain the 5 most common species of cave-dwelling mysids in the NW Mediterranean Sea (Hemimysis speluncola, Hemimysis margalefi, Hemimysis lamornae mediterranea, Siriella gracilipes, and Harmelinella mariannae), and 


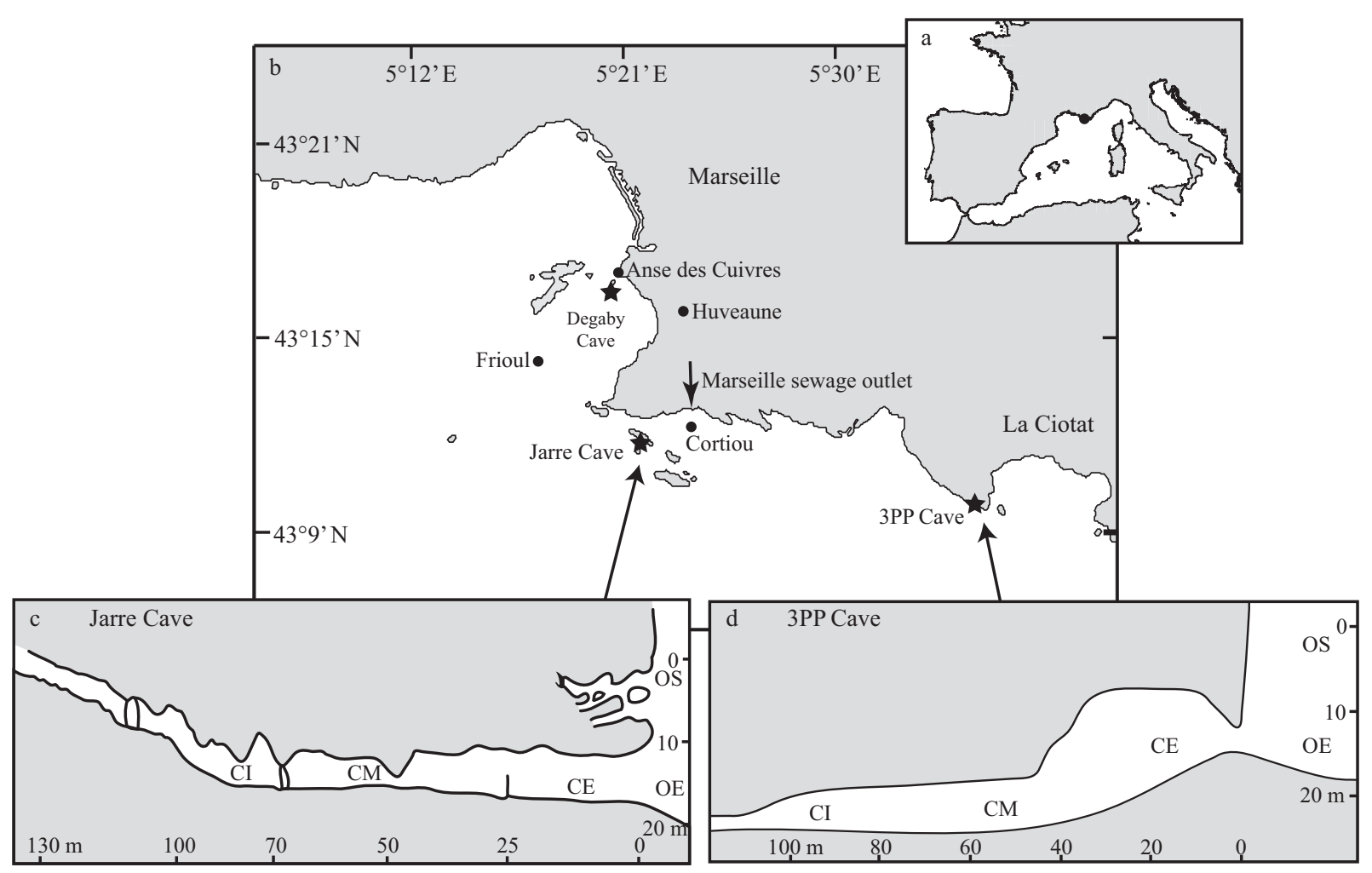

Fig. 1. (a) Location of Marseille in the NW Mediterranean; (b) location of the 3 marine caves studied ( $\star$ ) and additional sampling sites (•); (c) longitudinal section of Jarre Cave; (d) longitudinal section of 3PP Cave. Vertical scale, depth (m); horizontal scale, distance from cave entrance $(\mathrm{m})$. OS: outside at the sea surface; OE: outside at cave entrance depth; CE: inside at cave entrance; $\mathrm{CM}$ : inside in the middle of cave; CI: inside in the innermost part of cave

their potential predators and prey. Because part of some mysid diets is reported to be made up of detritus and organic matter (Riera et al. 1991, Coma et al. 1997), sedimentary organic matter (SOM) and suspended particulate organic matter (POM) were sampled inside and outside the caves. Sampling was done by SCUBA diving during winter 2009-10 at Jarre and 3PP and in September 2010 at Degaby. Mysids were sampled using a hand-operated suction bottle (Chevaldonné et al. 2008), then identified and sorted in vivo under a dissecting microscope. When possible, juveniles and adults (immature and mature) were separated following Tattersall \& Tattersall (1951) and Lejeusne \& Chevaldonné (2005), since their diet may differ (Takahashi 2004). When not possible, only adults were used. Teleost fishes and decapod crustaceans were sampled by spearfishing, hand nets, and hand picking. Fishes were put into individual zip bags in situ to avoid loss of stomach contents during surface recovery. Total length $(\mathrm{cm}, \mathrm{TL})$ and weight $(g, W)$ were recorded, and gut contents preserved in $95 \%$ ethanol. The carnivorous cladorhizid sponge Asbestopluma hypogea was also sampled, as it has been experimentally demonstrated to be a potential predator of mysids (Vacelet \& Duport 2004). Copepods were sampled using a $70 \mu \mathrm{m}$ mesh net handled by SCUBA divers in caves. Zooplankton was sampled by vertical tows using a $200 \mu \mathrm{m}$ mesh net just outside the cave entrance. Samples were prefiltered on $2000 \mu \mathrm{m}$ mesh in order to remove large detritus and gelatinous organisms. All samples were maintained at $4^{\circ} \mathrm{C}$ during transport, then stored at $-20^{\circ} \mathrm{C}$ and freeze dried before being processed for stable isotope analyses. SOM was sampled by skimming the sediment surface (0 to $1 \mathrm{~cm}$ ) with glass vials at different positions inside and outside caves (Fig. 1). Suspended POM samples were obtained by collecting $40 \mathrm{l}$ of seawater using diver-operated Niskin bottles inside caves, outside caves at entrance depth, and from surface water immediately above caves (Fig. 1). Seawater was prefiltered on a $200 \mu \mathrm{m}$ mesh sieve to remove large detritus and zooplankton, and filtered on pre-weighed, precombusted $\left(500^{\circ} \mathrm{C}\right.$, $4 \mathrm{~h}$ ) Whatman GF/F filters to obtain a minimum of 4 filters per site. Filters were then dried at $50^{\circ} \mathrm{C}$, weighed to quantify suspended particulate matter 
(SPM) content, and kept in a dark dry place until stable isotope analysis. SPM quantification is an assessment of the amount of both organic and inorganic materials that can be found in the water column. Additional data on suspended POM from different sites were obtained from previous studies for comparison: Frioul Islands in the Bay of Marseille, Anse des Cuivres on the mainland in the Bay of Marseille, Cortiou sewage outlet on the Calanques coast, Huveaune River in the Bay of Marseille as well as the Rhône River (Fig. 1) (Darnaude et al. 2004, HarmelinVivien et al. 2010, Topçu et al. 2010, P. Cresson unpubl. data, M. Harmelin-Vivien unpubl. data).

Although the model proposed here of the trophic dynamics of underwater marine caves is primarily based on the main Jarre and 3PP Caves, stable isotopic compositions of the mysids sampled from the smaller Degaby Cave were used as a comparison, since we could verify that water masses had similar signatures in all three caves (see 'Results' and Fig. 5).

\section{Stable isotope analysis}

Fish dorsal muscle was used for stable isotope analyses, since muscle isotopic composition is less variable than in other tissues (Pinnegar \& Polunin 1999). Only muscle tissues of the abdomen, legs, or chelipeds of decapods were used for stable isotope analyses to avoid the exoskeleton, which contains inorganic carbon. Mysids, copepods, and sponges were analyzed by pooling a variable number of whole individuals to reach mass requirements of the isotopic analysis. Freeze-dried samples were ground into a fine homogeneous powder using a mortar and pestle, and the surfaces of dried filters were scraped to collect POM material for analyses. As inorganic carbon is higher in ${ }^{13} \mathrm{C}$ carbonates than organic matter (Deniro \& Epstein 1978), samples with carbonates are commonly decalcified using $\mathrm{HCl}$ before analysis. However, acidification can alter $\delta^{15} \mathrm{~N}$ measurements increasing their values (Pinnegar \& Polunin 1999). Therefore we divided POM, SOM, copepods, and zooplankton samples into 2 subsamples. One subsample (for carbon isotope analysis) was acidified with $1 \mathrm{~N} \mathrm{HCl}$ solution overnight then rinsed with distilled water 3 times and oven dried at $50^{\circ} \mathrm{C}$ overnight to remove carbonates. The other subsample (for nitrogen isotope analysis) was not acidified. Fish and decapod muscle tissues were used without acidification, as well as mysids for which previous analyses indicated no change in $\delta^{13} \mathrm{C}$ values after acidification (C. Lejeusne, P. Chevaldonné, M. Harmelin-Vivien unpubl. data). Stable isotope measurements were performed using a continuous-flow isotope-ratio mass spectrometer (Delta V Advantage, Thermo Scientific) coupled to an elemental analyzer (Flash EA1112, Thermo Scientific). Isotope ratios were expressed as parts per thousand (\%) relative to Pee Dee Belemnite $\delta^{13} \mathrm{C}$ and atmospheric $\mathrm{N}_{2} \delta^{15} \mathrm{~N}$ according to the equation:

$$
\delta X(\%)=\left(\frac{R_{\text {sample }}}{R_{\text {standard }}}-1\right) \times 10^{3}
$$

where $X$ is ${ }^{13} \mathrm{C}$ or ${ }^{15} \mathrm{~N}$, and $R$ the corresponding ratio ${ }^{13} \mathrm{C}:{ }^{12} \mathrm{C}$ or ${ }^{15} \mathrm{~N}:{ }^{14} \mathrm{~N}$. For both $\delta^{13} \mathrm{C}$ and $\delta^{15} \mathrm{~N}$, measurement precision is $<0.1 \%$ (replicate measurements of internal laboratory standards, acetanilide). Percentages of organic $\mathrm{C}$ and organic $\mathrm{N}$ of samples were obtained using the elemental analyzer and have been used to calculate the C:N ratio. Data are expressed as means \pm SD.

Stable isotope ratios can be used to reconstruct trophic webs as the usual mean fractionation factor between prey and predator is considered to be +0.4 to $2 \%$ for $\delta^{13} \mathrm{C}$ values and +2.5 to $4.5 \%$ for $\delta^{15} \mathrm{~N}$ values (Post 2002), although these mean fractionation values are questioned (Buchheister \& Latour 2010).

\section{Data analyses}

Diets of adults of the 5 species of cave-dwelling mysids were reconstructed using IsoSource software (Phillips \& Gregg 2003). This procedure calculates possible combinations (in 1\% increments) of fooditem stable isotope compositions to explain consumer isotope compositions. We included all potential food sources in the analysis (Frioul POM, POM from outside caves, SOM from outside and inside caves, outside zooplankton, and Jarre Cave's copepods Ridgewayia cf. marki minorcaensis) except POM from inside caves because preliminary tests (data not shown) revealed that this item always had a negligible contribution to consumer stable isotope compositions. Before the analysis, food items must be corrected with a fractionation factor. The carbon fractionation factor value $(1.8 \%)$ was chosen as the mean between the most commonly used fractionation factor for carbon signatures $(1 \%)$ and an upper-bound fractionation factor value found for mysids $(2.6 \%$; Gorokhova \& Hansson 1999). The nitrogen fractionation factor used $(2.9 \%$ ) was the mean between 2.2 and $3.6 \%$, which represent the range of values available for mysids (Gorokhova \& Hansson 1999, Lesutiene et al. 2007). Data are expressed as mean \pm SD. 
One- and 2-way analyses of variance (ANOVA) were performed on $\delta^{13} \mathrm{C}, \delta^{15} \mathrm{~N}, \% \mathrm{C}, \% \mathrm{~N}, \mathrm{C}: \mathrm{N}$ values, and suspended POM. Homogeneity of variances was tested using the Levene test prior to analyses, and means were compared using post-hoc StudentNewman-Keuls tests. If variances were not homogeneous to perform 2-way ANOVAs, 1-way ANOVAs were conducted. Then, if variances were not homogenous to perform 1-way ANOVAs, non-parametric Kruskal-Wallis tests were conducted. These statistical analyses were conducted to assess the effects of cave or sample position and the combination of these 2 factors for 2-way ANOVA. Differences were judged significant when $\mathrm{p}<0.05$. Hierarchical ascending cluster analyses based on Euclidean distances of $\delta^{13} \mathrm{C}$ and $\delta^{15} \mathrm{~N}$ values were performed to help identify groups among the different mysid species and among POM samples from caves and additional sites from previous studies. All analyses were performed using the STATISTICA version 6.1 program.

\section{RESULTS}

\section{Difference in isotopic compositions among mysids}

Most of the 5 cave-dwelling mysid species collected near Marseille presented different isotopic signatures (Fig. 2). Hemimysis speluncola differed from all the other species by low $\delta^{13} \mathrm{C}\left(<-20.0 \%\right.$ o) and low $\delta^{15} \mathrm{~N}$ values $(<5.5 \%)$, whereas Harmelinella mariannae was distinguished by a high $\delta^{15} \mathrm{~N}(>9.0 \%$ ). Hemimysis

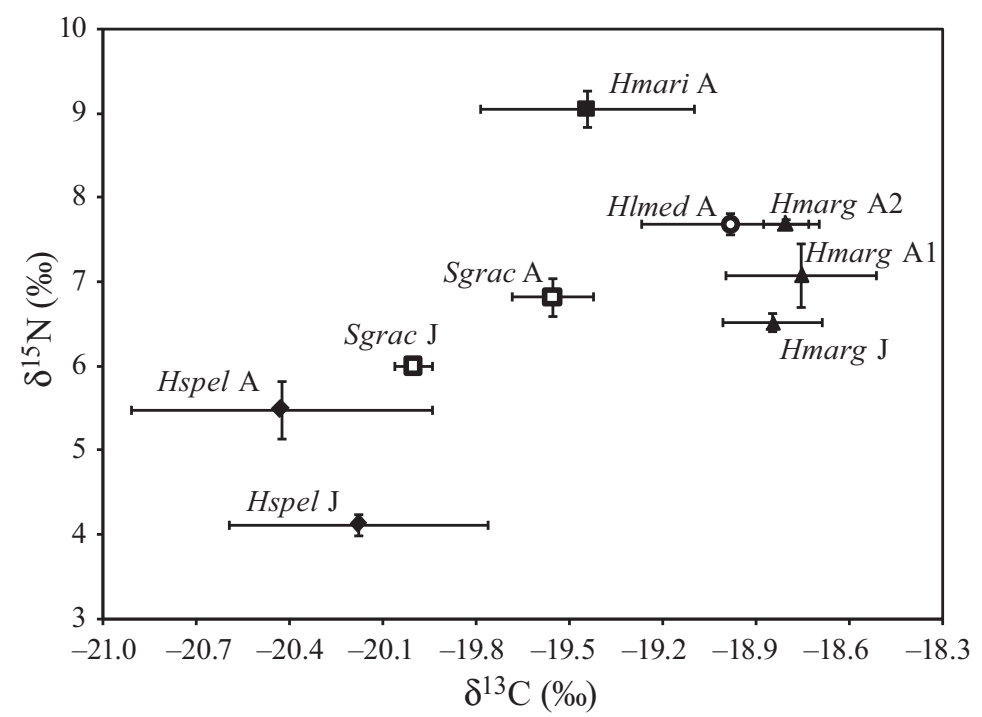

Fig. 2. Dual isotope plot of $\delta^{13} \mathrm{C}$ and $\delta^{15} \mathrm{~N}$ (mean \% $\pm \mathrm{SD}$ ) for the 5 mysid species studied in marine caves. 1: Jarre Cave; 2: Degaby Cave. See Table 1 for further abbreviations lamornae mediterranea and Hemimysis margalefi did not differ significantly from each other and were characterized by high values of $\delta^{13} \mathrm{C}(>-19.0 \%$ ) and medium $\delta^{15} \mathrm{~N}$ values (6.5 to $7.8 \%$ ). Siriella gracilipes also presented medium values of $\delta^{15} \mathrm{~N}$ (6.0 to $6.9 \%$ ) but differed from the 2 previous species by lower $\delta^{13} \mathrm{C}$ values ( -20.0 to $-19.5 \%$ ). These mysid species seem to rely on different food sources, with Harmelinella mariannae presenting the highest trophic position and Hemimysis speluncola the lowest. For the 3 species in which size could be taken into consideration ( $H$. speluncola, $H$. margalefi, and $S$. gracilipes), juveniles always displayed lower $\delta^{15} \mathrm{~N}$ values than adults, suggesting a different diet and/or a higher growth rate in juveniles than adults (Fig. 2).

\section{Trophic relationships of cave-dwelling organisms}

$\mathrm{C}$ and $\mathrm{N}$ stable isotope ratios measured in the cavedwelling organisms presented very similar values in the 2 caves studied (Table 1), and their relative trophic position was consistent. For example, the species with the highest $\delta^{15} \mathrm{~N}$ values are the same in the 2 caves. We constructed a bi-plot with mean $( \pm \mathrm{SD}) \delta^{13} \mathrm{C}$ and $\delta^{15} \mathrm{~N}$ values, representing the mean trophic position of all the organisms collected in our case studies of NW Mediterranean caves (Fig. 3). The highest trophic position was occupied by the 2 fish species analysed, Thorogobius ephippiatus and Apogon imberbis, and by the carnivorous sponge Asbestopluma hypogea, known to feed on crustaceans. Juvenile $A$. imberbis presented lower $\delta^{15} \mathrm{~N}$ values than adults $(6.18 \pm 0.85 \%$ and $9.97 \pm 0.39 \%$, respectively) in accordance with their diet. Gut contents of juvenile $A$. imberbis revealed they had ingested mainly small amphipods and shrimps, whereas adult diet was mainly composed of shrimps, amphipods, and polychaetes of larger size. In contrast, T. ephippiatus had mainly preyed on polychaetes, gastropods, bivalves, foraminiferans, and crustaceans including mysids, shrimps, crabs, amphipods, isopods, and harpacticoid copepods. Among the crustaceans sampled, the 3 shrimp species (Lysmata nilita, Stenopus spinosus, and Palaemon serratus) presented higher $\delta^{15} \mathrm{~N}$ (9.31 to $9.92 \%$ ) and $\delta^{13} \mathrm{C}(-17.64$ to $-16.74 \%$ ) values than the majid crab Herbstia condyliata and the anomuran crab Galathea strigosa $\left(\delta^{15} \mathrm{~N} \sim 8 \%\right.$, $\delta^{13} \mathrm{C} \sim-18 \%$ o). Interestingly the cave-dwelling copepod Ridgewayia cf. marki minorcaensis 
Table 1. Mean $( \pm \mathrm{SD}) \delta^{13} \mathrm{C}$ and $\delta^{15} \mathrm{~N}$ values of organisms collected at Jarre, 3PP, and Degaby marine caves. Mean size is provided for fish. n: number of samples; TL: total length

\begin{tabular}{|c|c|c|c|c|c|c|}
\hline Species & ogenetic stage & Abbreviation & $\delta^{13} \mathrm{C}(\%)$ & $\delta^{15} \mathrm{~N}(\%)$ & $\mathrm{n}$ & $\mathrm{TL}(\mathrm{cm})$ \\
\hline \multicolumn{7}{|l|}{ Jarre Cave } \\
\hline Asbestopluma hypogea & & Ahyp & $-18.52 \pm 0.43$ & $10.44 \pm 0.05$ & 3 & \\
\hline \multirow{2}{*}{ Apogon imberbis } & Adult & Aimb A & $-18.65 \pm 0.52$ & $10.06 \pm 0.39$ & 12 & $9.98 \pm 0.50$ \\
\hline & Juvenile & Aimb J & $-18.13 \pm 0.19$ & $6.43 \pm 1.17$ & 6 & $3.35 \pm 0.78$ \\
\hline Thorogobius ephippiatus & & Tephi & $-18.45 \pm 0.16$ & $10.36 \pm 0.27$ & 12 & $5.98 \pm 0.59$ \\
\hline Galathea strigosa & & Gstri & $-18.04 \pm 0.04$ & $7.94 \pm 0.13$ & 3 & \\
\hline Herbstia condyliata & & Hcon & $-18.18 \pm 0.18$ & $8.41 \pm 0.15$ & 6 & \\
\hline Lysmata nilita & & Lnil & $-16.74 \pm 0.05$ & $9.92 \pm 0.15$ & 3 & \\
\hline Palaemon serratus & & Pser & $-18.29 \pm 0.65$ & $9.06 \pm 0.38$ & 9 & \\
\hline Stenopus spinosus & & Sspi & $-17.14 \pm 0.14$ & $9.83 \pm 0.08$ & 6 & \\
\hline Ridgewayia cf. marki minorcaensis & & Rmami & $-21.87 \pm 0.33$ & $7.60 \pm 0.30$ & 5 & \\
\hline \multirow[t]{2}{*}{ Hemimysis margalefi } & Adult & Hmarg A1 & $-18.16 \pm 0.24$ & $7.08 \pm 0.38$ & 11 & \\
\hline & Juvenile & Hmarg J & $-18.85 \pm 0.16$ & $6.52 \pm 0.11$ & 6 & \\
\hline Harmelinella mariannae & Adult & Hmari & $-19.45 \pm 0.34$ & $9.06 \pm 0.21$ & 6 & \\
\hline Zooplankton & & Zoo & $-21.71 \pm 0.23$ & $3.08 \pm 0.59$ & 6 & \\
\hline \multicolumn{7}{|l|}{ 3PP Cave } \\
\hline Asbestopluma hypogea & & Ahyp & $-18.00 \pm 0.10$ & $9.95 \pm 0.04$ & 3 & \\
\hline \multirow{2}{*}{ Apogon imberbis } & Adult & Aimb A & $-18.37 \pm 0.04$ & $9.64 \pm 0.08$ & 6 & $11.5 \pm 0.00$ \\
\hline & Juvenile & $A i m b \mathrm{~J}$ & $-18.26 \pm 0.06$ & $5.92 \pm 0.26$ & 3 & $3.6 \pm 0.28$ \\
\hline Thorogobius ephippiatus & & Tephi & $-17.66 \pm 0.10$ & $10.96 \pm 0.49$ & 9 & $6.8 \pm 0.70$ \\
\hline Palaemon serratus & & Pser & $-16.98 \pm 0.71$ & $9.56 \pm 0.32$ & 9 & \\
\hline \multirow[t]{2}{*}{ Hemimysis speluncola } & Adult & Hspel A & $-20.43 \pm 0.48$ & $5.49 \pm 0.34$ & 12 & \\
\hline & Juvenile & Hspel J & $-20.18 \pm 0.42$ & $4.12 \pm 0.13$ & 2 & \\
\hline Zooplankton & & Zoo & $-22.03 \pm 0.07$ & $2.03 \pm 0.13$ & 3 & \\
\hline \multicolumn{7}{|l|}{ Degaby Cave } \\
\hline \multirow[t]{2}{*}{ Siriella gracilipes } & Adult & Sgrac A & $-19.56 \pm 0.13$ & $6.83 \pm 0.23$ & 6 & \\
\hline & Juvenile & Sgrac J & $-20.00 \pm 0.06$ & $6.01 \pm 0.08$ & 6 & \\
\hline Hemimysis margalefi & Adult & Hmarg A2 & $-18.81 \pm 0.07$ & $7.70 \pm 0.04$ & 4 & \\
\hline Hemimysis lamornae mediterranea & Adult & Hlmed & $-18.98 \pm 0.29$ & $7.68 \pm 0.13$ & 6 & \\
\hline
\end{tabular}

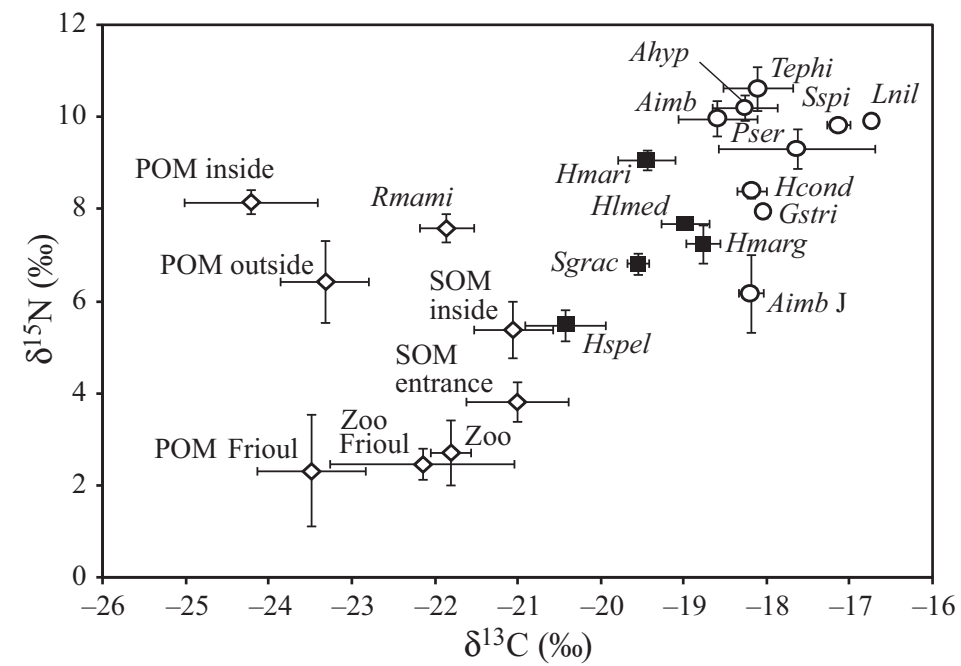

Fig. 3. Dual isotope plot of $\delta^{13} \mathrm{C}$ and $\delta^{15} \mathrm{~N}$ (mean \%o $\pm \mathrm{SD}$ ) for the food web components of underwater caves in the Marseille area. Cave-dwelling mysids ( $\boldsymbol{\square})$, other cave dwellers ( $(\mathbf{0})$, and potential food sources $(\diamond)$ are indicated. Only adults are represented unless otherwise stated. J: juveniles. POM (SOM): particulate (sedimentary) organic matter. See Table 1 for further abbreviations displayed a higher $\delta^{15} \mathrm{~N}$ value $(7.60 \pm 0.30 \%$ o than most mysids, except Harmelinella mariannae. Finally, mysids occupy a rather low trophic position in the cave food web, except for $H$. mariannae (Fig. 3), consistent with the general knowledge about mysid feeding habits.

Applying the mixing model IsoSource to stable isotope compositions of adult mysids suggested that Hemimysis speluncola may rely exclusively on phytoplankton and zooplankton (27 and 70\%, respectively; Fig. 4). $H$. margalefi and $H$. lamornae mediterranea seemed to have a diet made of the same items: SOM from both inside and outside caves but in different amounts (Fig. 4). In addition, H. 1. mediterranea seemed to feed also on zooplankton and small crustaceans (5 and $7 \%$, respectively; Fig. 4). The diet of Harmelinella mariannae appeared to be mostly made up of food sources from inside 

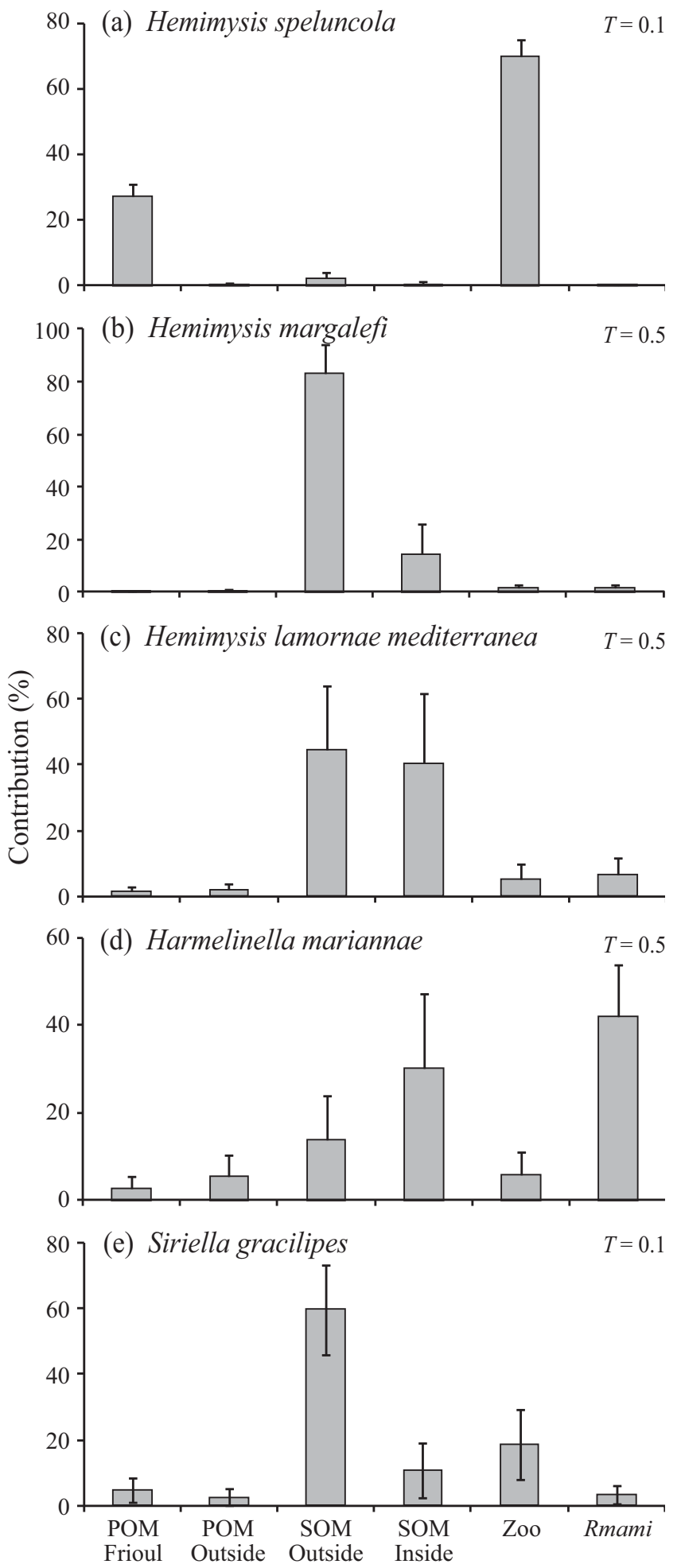

Fig. 4. Comparison of the average contribution of each food item to the diet of 5 cave-dwelling mysids computed with the IsoSource model based on their stable isotope ratios: (a) Hemimysis speluncola, (b) Hemimysis margalefi, (c) Hemimysis lamornae mediterranea, (d) Harmelinella mariannae, and (e) Siriella gracilipes. POM (SOM): particulate (sedimentary) organic matter. $T$ : accepted tolerance value $( \pm \%$ o) caves (small cave-dwelling crustaceans, 42\%, and SOM from inside cave, $30 \%$; Fig. 4), whereas Siriella gracilipes appeared to feed mostly on outside food sources such as SOM (60\%) and zooplankton (19\%).

\section{Origin of the carbon entering marine cave systems}

Three types of carbon sources can be part of the diet of cave-dwelling mysids: marine phytoplankton (e.g. as measured as POM at Frioul), the water POM present just outside and inside the cave, or the SOM settled on cave bottom (Fig. 3). The $\delta^{13} \mathrm{C}$ and $\delta^{15} \mathrm{~N}$ values of POM from the Frioul site, far from the coast, are representative of offshore marine POM (-23.50 \pm $0.65 \%$ and $2.33 \pm 1.21 \%$, respectively), whereas suspended POM collected just outside the cave exhibited similar $\delta^{13} \mathrm{C}(-23.34 \pm 0.53 \%$ o) but much higher $\delta^{15} \mathrm{~N}$ values $(6.42 \pm 0.89 \%$ o). Suspended POM inside the cave presented even higher $\delta^{15} \mathrm{~N}(8.15 \pm 0.26 \%$ ), but lower $\delta^{13} \mathrm{C}$ values $(-24.22 \pm 0.80 \%$ o). SOM collected at the entrance of caves presented intermediate values $\left(\delta^{13} \mathrm{C}=-21.01 \pm 0.62 \%\right.$; $\delta^{15} \mathrm{~N}=3.82 \pm$ $0.43 \%$ ) between offshore marine and cave POM, and seemed to be composed by a mix of these 2 sources of organic matter that settled there. Inside the caves, SOM displayed similar $\delta^{13} \mathrm{C}(-21.07 \pm 0.47 \%$ o $)$ but higher $\delta^{15} \mathrm{~N}$ values $(5.40 \pm 0.62 \%)$ than outside SOM, as observed for suspended POM.

To determine why stable isotope values differed between marine POM and POM collected just outside the caves (close to the coast), we compared them with suspended POM isotopic signatures obtained from other coastal sites (Anse des Cuivres) or other periods (Frioul 2000-01), and from POM brought to the sea either by rivers (Rhône, Huveaune) or a sewage plant (Cortiou) (Fig. 4). A cluster analysis performed on $\delta^{13} \mathrm{C}$ and $\delta^{15} \mathrm{~N}$ values differentiated 4 groups (Fig. 5), one corresponding to continental POM inputs from rivers characterized by low $\delta^{13} \mathrm{C}$ $\left(-28.5\right.$ to $-25.8 \%$ ) and high $\delta^{15} \mathrm{~N}(3.5$ to $7.0 \%$ ). POM issued from the Cortiou sewage plant was differentiated by low $\delta^{13} \mathrm{C}(\sim-25 \%)$ and very low $\delta^{15} \mathrm{~N}(\sim 0 \%)$ likely due to chemical treatment of waste waters. Offshore marine POM (Frioul), whatever the year, was characterized by higher $\delta^{13} \mathrm{C}(-24$ to $-22 \%$ ) and low $\delta^{15} \mathrm{~N}$ (1.5 to $3.8 \%$ o). The fourth cluster gathered all data from the 3 cave sites (outside and inside) and the Anse des Cuivres, a very coastal site. The isotopic compositions of water POM from the sea surface or at the depths of cave entrances were similar. Measurements repeated at Jarre at a 1 yr interval were also similar ( $p>0.05$ for all; Fig. 5). Coastal water POM, 


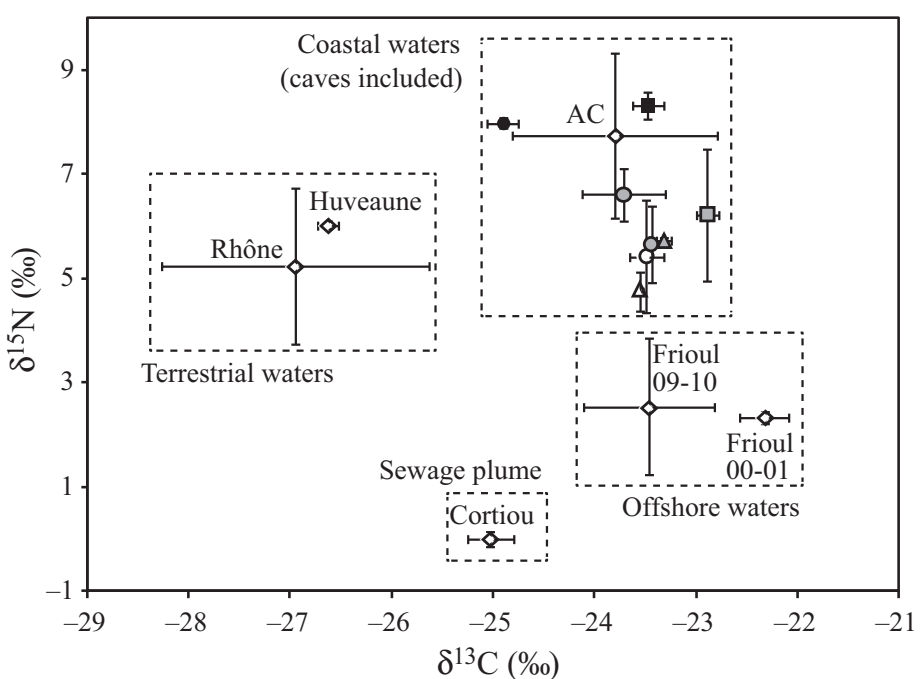

Fig. 5. Dual isotope plot of $\delta^{13} \mathrm{C}$ and $\delta^{15} \mathrm{~N}$ (mean \% \pm $\mathrm{SD})$ of the particulate organic matter (POM) of water masses at Jarre (0), 3PP (ם), and Degaby ( $\Delta$ ). Empty symbols correspond to surface water masses, grey symbols correspond to water masses outside marine caves at entrance depth, and black symbols to water masses from the middle part of caves. Data on surfacewater POM from additional sampling sites $(\diamond)$ were available for the Rhône River (Harmelin-Vivien et al. 2010), the Huveaune River (P. Cresson unpubl. data), the Cortiou sewage plume (Topçu et al. 2010), the Frioul site (Darnaude et al. 2004, M. Harmelin-Vivien unpubl. data), and the Anse des Cuivres coastal station (AC; M. Harmelin-Vivien unpubl. data). Boxes are the result of a hierarchical cluster analysis

Table 2. Characteristics of suspended particulate organic matter (POM) and sedimentary organic matter (SOM) sampled in Jarre and 3PP Caves (mean \pm SD). SPM: suspended particulate matter; n: number of samples; OE: outside at cave entrance depth; CE: inside at cave entrance; CM: inside in the middle of cave; CI: inside in the innermost part of cave; '-': not applicable

\begin{tabular}{|c|c|c|c|c|c|c|c|c|}
\hline Sampling site / position & $\mathrm{n} \quad \delta^{13} \mathrm{C}(\%)$ & $\delta^{15} \mathrm{~N}(\%)$ & $\% \mathrm{C}$ & $\% \mathrm{~N}$ & $C: N$ & $\mathrm{n}$ & $\mathrm{SPM}\left(\mathrm{mg} \mathrm{l}^{-1}\right)$ & $\mathrm{n}$ \\
\hline \multicolumn{9}{|l|}{ POM } \\
\hline Jarre-OE & $-23.75 \pm 0.41$ & $6.61 \pm 0.50$ & $1.57 \pm 0.31$ & $0.34 \pm 0.20$ & $5.22 \pm 1.74$ & 3 & $0.77 \pm 0.18$ & 4 \\
\hline Jarre-CM & $-24.94 \pm 0.15$ & $7.99 \pm 0.10$ & $3.09 \pm 0.27$ & $0.40 \pm 0.05$ & $7.83 \pm 1.62$ & 3 & $0.54 \pm 0.03$ & 6 \\
\hline 3PP-OE & $-22.92 \pm 0.11$ & $6.23 \pm 1.27$ & $3.83 \pm 1.43$ & $0.64 \pm 0.15$ & $6.65 \pm 4.30$ & 3 & $0.76 \pm 0.10$ & 4 \\
\hline 3PP-CM & $-23.51 \pm 0.16$ & $8.32 \pm 0.27$ & $2.21 \pm 0.66$ & $0.39 \pm 0.06$ & $5.54 \pm 0.74$ & 3 & $0.50 \pm 0.03$ & 6 \\
\hline \multicolumn{9}{|l|}{ SOM } \\
\hline Jarre-OE & $-21.34 \pm 0.12$ & $3.32 \pm 0.10$ & $6.90 \pm 1.32$ & $0.11 \pm 0.01$ & $62.19 \pm 15.41$ & 3 & - & - \\
\hline Jarre-CE & $-21.69 \pm 0.22$ & $4.22 \pm 0.16$ & $6.95 \pm 0.43$ & $0.20 \pm 0.01$ & $35.53 \pm 2.94$ & 6 & - & - \\
\hline Jarre-CM & $-21.90 \pm 0.11$ & $5.07 \pm 0.19$ & $0.67 \pm 0.01$ & $0.05 \pm 0.00$ & $12.95 \pm 0.17$ & 3 & - & - \\
\hline Jarre-CI & $-21.18 \pm 0.08$ & $5.96 \pm 0.90$ & $0.49 \pm 0.04$ & $0.03 \pm 0.00$ & $16.74 \pm 1.58$ & 3 & - & - \\
\hline 3PP-OE & $-20.43 \pm 0.16$ & $3.57 \pm 0.39$ & $0.50 \pm 0.05$ & $0.08 \pm 0.01$ & $6.10 \pm 0.75$ & 6 & - & - \\
\hline 3PP-CE & $-20.48 \pm 0.35$ & $4.01 \pm 0.04$ & $3.68 \pm 0.55$ & $0.17 \pm 0.01$ & $21.78 \pm 2.54$ & 3 & - & - \\
\hline 3PP-CM & $-20.78 \pm 0.07$ & $5.28 \pm 0.67$ & $2.23 \pm 0.06$ & $0.11 \pm 0.00$ & $21.07 \pm 0.76$ & 6 & - & - \\
\hline 3PP-CI & $-20.68 \pm 0.04$ & $5.39 \pm 0.09$ & $2.07 \pm 0.01$ & $0.09 \pm 0.00$ & $24.07 \pm 0.20$ & 3 & - & - \\
\hline
\end{tabular}

including from caves, therefore presented medium $\delta^{13} \mathrm{C}$ values ( -25.1 to $-22.7 \%$ ), intermediate between offshore marine and continental $\delta^{13} \mathrm{C}$ POM values, but high and variable $\delta^{15} \mathrm{~N}$ values (4.5 to $9.2 \%$ ), likely due to runoff inputs of anthropogenic and animal waste material.

\section{Oligotrophy in marine caves}

POM sampling outside and inside Jarre and 3PP Caves, and SOM sampling outside caves and along the gradient inside caves, revealed main peculiarities of POM and SOM inside caves (Tables $2 \& 3$ ). In the 2 caves, POM $\delta^{13} \mathrm{C}$ significantly decreased inside along with the quantity of SPM, whereas POM $\delta^{15} \mathrm{~N}$ increased. All the other parameters analyzed $(\% \mathrm{C}$, $\% \mathrm{~N}$, and $\mathrm{C}: \mathrm{N}$ ) did not differ between outside and inside waters at Jarre, but lower \% $\mathrm{C}$ and $\% \mathrm{~N}$ values were recorded inside 3PP Cave. The low $\mathrm{C}: \mathrm{N}$ value of water POM at the 2 sites seems to indicate a rather fresh organic material, both outside and inside, but in lower quantity inside the caves. POM $\delta^{13} \mathrm{C}$ values were significantly lower at Jarre than at 3PP, both outside and inside the cave, while $\delta^{15} \mathrm{~N}$ did not differ between the 2 caves.

SOM characteristics displayed similar variation with location in the 2 caves (Tables $2 \& 3$ ). A slight, often non-significant decrease was observed for $\mathrm{SOM} \delta^{13} \mathrm{C}$ values from outside to the innermost part of the cave, 
Table 3. Statistical tests of the effects of cave (Jarre vs. 3PP) and position of sampling (out, entrance, middle, innermost part) on the parameters describing suspended POM and SOM at Jarre and 3PP Caves. H: Kruskal-Wallis non-parametric test;

F: 1- or 2-way ANOVA. Level of significance: ${ }^{*} \mathrm{p}<0.05,{ }^{* *} \mathrm{p}<0.01,{ }^{* * *} \mathrm{p}<0.001$. See Table 2 for further abbreviations

\begin{tabular}{|c|c|c|c|c|c|c|c|}
\hline Sample type & Factor analyzed & $\delta^{13} \mathrm{C}$ & $\delta^{15} \mathrm{~N}$ & $\% \mathrm{C}$ & $\% \mathrm{~N}$ & $\mathrm{C}: \mathrm{N}$ & SPM \\
\hline POM & $\begin{array}{c}\text { Cave } \\
\text { Position } \\
\text { Cave } \times \text { Position }\end{array}$ & $\begin{array}{c}H=5.77^{*} \\
H_{\text {Jarre }}=3.86^{* *} \\
H_{3 \mathrm{PP}}=3.86^{* *}\end{array}$ & $\begin{array}{c}F=0.00 \\
F=18.55^{* *}\end{array}$ & $\begin{array}{c}F=2.13 \\
F=0.01 \\
F=11.24^{*}\end{array}$ & $\begin{array}{l}F=3.60 \\
H=0.92\end{array}$ & $\begin{array}{l}F=0.09 \\
F=0.27\end{array}$ & $\begin{array}{c}F=0.22 \\
H=11.01^{* * *}\end{array}$ \\
\hline SOM & $\begin{array}{c}\text { Cave } \\
\text { Position }\end{array}$ & $\begin{array}{c}H=21.77^{* * *} \\
F_{\text {Jarre }}=12.32^{* * *} \\
H_{3 \mathrm{PP}}=6.30\end{array}$ & $\begin{array}{c}F=0.83 \\
F=37.31^{* * *}\end{array}$ & $\begin{array}{c}H=2.17 \\
H=13.22^{* *}\end{array}$ & $\begin{array}{c}H=0.10 \\
H=19.20^{* * *}\end{array}$ & $\begin{array}{l}H=2.82 \\
H=6.88\end{array}$ & $\begin{array}{l}- \\
-\end{array}$ \\
\hline
\end{tabular}

whereas an increase in SOM $\delta^{15} \mathrm{~N}$ occurred. Parameters $\% \mathrm{C}, \% \mathrm{~N}$, and C:N generally presented their highest values at the entrance of the cave, suggesting rapid accumulation of organic matter after entering the cave. In the middle and innermost parts of caves, SOM experienced a sharp decrease in $\% \mathrm{C}$ and $\% \mathrm{~N}$ values, indicating a lower organic content in SOM at these locations. This phenomenon was more pronounced at Jarre than at 3PP. C:N values were higher outside and at the Jarre entrance, where an accumulation of plant detritus was observed. The increase in SOM C:N values inside 3PP suggests an accumulation of refractory material near the end of the cave. As observed for suspended POM, SOM $\delta^{13} \mathrm{C}$ values were also lower at Jarre than at 3PP, while no difference was observed for $\delta^{15} \mathrm{~N}$ values. Thus, both POM and SOM decreased in quantity and quality inside caves, which is in good agreement with the confinement and trophic gradient reported in caves.

\section{DISCUSSION}

Marine caves are particular oligotrophic environments, dependent on allochthonous carbon sources for their functioning (Harmelin et al. 1985, Fichez 1990). Mysids are key components of marine cave communities, but little was known on their place in the trophic web of these ecosystems. The use of stable isotope analyses at both Jarre and 3PP Caves allows us to construct, for the first time, a theoretical model to better understand the general functioning of trophic relationships among underwater cave mysids (Fig. 3). This model, along with observations on their behavior, allows some hypotheses to be drawn about their feeding strategies and role in the trophic functioning of Mediterranean caves.

\section{Feeding behavior of cave-dwelling mysids}

Mysids are often considered omnivorous consumers, feeding on a wide range of food items such as phytoplankton, zooplankton, detritus, seagrass, and algal filaments (Mauchline 1980, Dauby 1995, Takahashi 2004, Lehtiniemi \& Nordström 2008). However, little is known about the diet of cavedwelling mysids. The variety of feeding behavior in this group was emphasized in the present study by the markedly different stable isotope signatures recorded among 4 of the 5 species analyzed (Fig. 2), indicating different diets. The most extensive literature on cave-dwelling mysid feeding behavior relies on gut content and fecal pellet analyses of Hemimysis speluncola (Riera et al. 1991, Carola et al. 1993, Coma et al. 1997). These authors observed that $H$. speluncola performs circadian migrations, leaving the cave at night to feed on small organisms and detritus and returning inside the cave to shelter by day. Nocturnal migrations in $H$. speluncola have also been demonstrated in the caves near Marseille, including Jarre (Passelaigue \& Bourdillon 1986), when this species was still abundant there (Chevaldonné \& Lejeusne 2003). The nitrogen fractionation factor calculated for mysids and their prey ranges between 2.2 and 3.6\% (Gorokhova \& Hansson 1999, Lesutiene et al. 2007). The low $\delta^{15} \mathrm{~N}(5.5 \%)$ recorded in $H$. speluncola in the present study indicates that it could not rely on cave organic matter (such as settled SOM) that displays similar $\delta^{15} \mathrm{~N}(5.4 \%)$, but would be consistent with a mixed diet of outside marine phytoand zooplankton, presenting lower $\delta^{15} \mathrm{~N}$ values $(2.3$ and $2.6 \%$, respectively; Table 1) compatible with nitrogen fractionation, as indicated by the results of the mixing model (Fig. 4). Phytoplankton has previously been observed in this species' gut contents (Riera et al. 1991, Coma et al. 1997), and experimental studies have shown that it also feeds on small zoo- 
plankton such as harpacticoid copepods (Gaudy \& Guérin 1979). The migratory habits, isotopic compositions, and previously published observations all point towards a phytoplankton- and zooplanktonbased diet obtained outside the caves, the proportion of which may vary seasonally, regionally, or even from cave to cave. This is consistent with one of the typical mysid feeding modes, suspension feeding, in which small particles such as detritus, phytoplankton and small zooplankton are acquired (Takahashi 2004). At the other end of the spectrum, Harmelinella mariannae is a poorly known species, and no data exist on its feeding habits. The only observation is that this species is attracted by baited traps contrary to other cave-dwelling mysids, suggesting carnivory (Ledoyer 1989). Apparently, this mysid lives in the innermost part of caves and does not seem to ever leave them (Ledoyer 1989). The high $\delta^{15} \mathrm{~N}(9.1 \%)$ recorded in $H$. mariannae suggests a predatory or scavenging habit consistent with a diet based on small cave-dwelling crustaceans such as Ridgewayia. cf. marki minorcaensis $(7.6 \%)$ or others which likely feed on suspended POM entering the cave. The mixing model supports a large contribution $(42 \%)$ of small cave-dwelling crustaceans in the diet of this mysid. It also indicates that SOM from inside caves can contribute a large part of its diet $(30 \%$; Fig. 4). The combination of these 2 main sources is indeed compatible with the supposed predatory/ scavenging regime of $H$. mariannae. The abundant populations of mysids and small crustaceans such as copepods in cave waters ensure both the presence of live prey and of fresh carcasses on top of the sediment. To our knowledge nothing is known with certainty on the diet of Hemimysis margalefi and Hemimysis lamornae mediterranea. Their isotopic signatures and the mixing model suggest that these species have similar diets, likely constituted by POM settled on the bottom inside or outside caves and maybe, but in a lower proportion, by phyto- and zooplankton. It is not certain that $H$. margalefi can leave the caves at night as does $H$. speluncola, but at least it certainly moves towards the entrance (Benzid et al. 2006, Moscatello \& Belmonte 2007), where organic matter derived from plankton is more available. As a sciaphilic species, H. l. mediterranea has easy access to such organic matter by staying at the cave entrance during daytime and leaving the cave at night. The $\delta^{15} \mathrm{~N}$ value of SOM $(4.5 \%)$ available to these species suggests that it is composed of both offshore marine $(2.3 \%)$ and coastal material $(7.3 \%)$ entering the cave. The occasional consumption of higher $\delta^{15} \mathrm{~N}$ materials such as $R$. cf. marki minorcaensis and SOM from inside caves (rich in crustacean carcasses) suggested by the mixing model (Fig. 4) could explain the slightly higher nitrogen composition of H. l. mediterranea over $H$. margalefi. Perhaps its bigger size allows it to feed on larger, ${ }^{15} \mathrm{~N}$-rich carcasses. Little is known on the feeding habits of Siriella species. Reefdwelling species are supposed to feed almost exclusively on planktonic copepods and cladocerans (Hobson \& Chess 1976). In Mediterranean shallow benthic habitats, high $\delta^{15} \mathrm{~N}(6.8 \%)$ recorded in Siriella spp. closely related to Siriella gracilipes also suggest a zooplanktivorous diet (Pinnegar \& Polunin 2000). $S$. gracilipes stays at cave entrance during the day and leaves the cave at night (Wittmann 2001, Moscatello \& Belmonte 2007), making outside zooplankton an available food resource for this relatively large species. This is consistent with the mixing model which suggests a diet mostly derived from SOM from outside cave $(60 \%)$ and zooplankton (19\%; Fig. 4). An additional consumption of inside-cave food is also possible. It is consistent with the nitrogen composition of $S$. gracilipes (6.8\%; Table 1) found in this study, which indicates a mixed diet mostly based on outside-cave material such as SOM and zooplankton. Zooplankton collected outside the cave presents similar values of $\delta^{15} \mathrm{~N}$ to zooplankton collected at the Frioul site. It seems to feed on marine phytoplankton rather than on coastal POM. Finally, the low nitrogen composition of juveniles of $H$. speluncola, $H$. margalefi, and S. gracilipes compared to adults (Fig. 2) can be attributed to ontogenetic change in diet as juveniles prey on smaller items (Takahashi 2004, Lesutiene et al. 2007, Lehtiniemi \& Nordström 2008). Our limited Degaby Cave data were essentially acquired to provide an idea of the trophic position of S. gracilipes and H. 1. mediterranea relative to other species. It was not intended to address geographical and temporal variation of stable isotopic compositions (Lehtiniemi et al. 2009, Kurle et al. 2011). However, noteworthy differences in both the $\delta^{13} \mathrm{C}$ and $\delta^{15} \mathrm{~N}$ values of adult $H$. margalefi can be observed between Degaby and Jarre Cave that could be indicative of intraspecific variability in the mysids' feeding regimes depending on geography, cave environment, and/or seasons.

Differences of diet in co-occurring mysids are assumed to reduce interspecific competition and allowing coexistence (Winkler et al. 2007, Lehtiniemi et al. 2009), a mechanism particularly effective when food resources are scarce (Lehtiniemi \& Nordström 2008). This seems to be the case in the oligotrophic marine cave environment, as our isotopic results indicated a food partitioning among the 5 species studied. 
Resource partitioning in these species is also linked to habitat partitioning and differences in migratory patterns, since Hemimysis margalefi and H. lamornae mediterranea have similar isotopic signatures but very different ecological niches in the cave ecosystem.

\section{Carbon sources and oligotrophy in cave systems}

Like most aphotic systems, underwater caves rely on allochthonous sources of carbon. The marine caves studied here are supplied from shallow coastal waters. Diverse carbon sources may be involved in the studied caves, such as phytoplankton and materials from river runoff and sewage outflow. NW Mediterranean marine phytoplankton typically exhibits high $\delta^{13} \mathrm{C}$ values ( -21 to $-23 \%$ ) and low $\delta^{15} \mathrm{~N}$ (2 to $4 \%$ ) (Pinnegar \& Polunin 2000, Harmelin-Vivien et al. 2008) as does the POM sampled at Frioul site for this study $\left(\delta^{13} \mathrm{C},-24\right.$ to $-22 \%$; $\delta^{15} \mathrm{~N}, 1.5$ to $3.8 \%$ ). In contrast, river POM presents low $\delta^{13} \mathrm{C}$ values (-25 to $-27 \%$ ) and high $\delta^{15} \mathrm{~N}$ (5 to $7 \%$ ) (Harmelin-Vivien et al. 2010) as in the Huveaune River $\left(\delta^{13} \mathrm{C},-26.7 \%\right.$; $\delta^{15} \mathrm{~N}, 6.0 \%$ ), while the sewage outflow from the Marseille area presents a low $\delta^{15} \mathrm{~N}(\sim 0 \%$; Topçu et al. 2010). Our data of $C$ and $N$ stable isotope ratios of suspended POM (low $\delta^{13} \mathrm{C}$ and high $\delta^{15} \mathrm{~N}$ values; Table 2) seemed to indicate both a marine and continental origin (Fig. 5). Coastal POM is indeed a mixture of marine phytoplankton, land-derived material such as plant detritus, and anthropogenic materials brought to the sea by river runoff and sewage outflow. The lower $\delta^{13} \mathrm{C}$ values observed at Jarre compared to 3PP Cave could be the result of a higher influence at Jarre of terrestrial inputs due to the proximity of the Cortiou outflow. The influence of this sewage outlet on the upper levels of marine cave food webs of the 2 caves, however, appears to be negligible since it is not detected in the mysid isotopic compositions. Mysids are capable of choice in the range of available food sources (Lehtiniemi \& Nordström 2008) and may therefore select food items that are not ${ }^{13} \mathrm{C}$-poor carbonates; in a similar way some filter feeders are capable of choice in food sources, leading to negatively selecting material poor in ${ }^{13} \mathrm{C}$ carbonates (e.g. from a sewage outlet; Topçu et al. 2010).

Inside the caves, suspended POM and SOM undergo different transformations due to consumption by cave-dwelling organisms and degradation by microbial processes (Fichez 1990). As expected, SPM decreases sharply from the entrance to the innermost part of the cave. The lower concentration of SPM inside can be attributed to sedimentation and consumption by dense populations of filter feeders in the twilight zone at the entrance of caves (Fichez 1991a, Palau et al. 1991, Garrabou \& Flos 1995). SPM decrease is generally reflected by a decline in $\% \mathrm{C}$ and $\% \mathrm{~N}$ values (Fichez 1991c), which has been observed in the 3PP Cave but not at Jarre. This might result from a greater water flow in this latter cave, at least at the sampling location inside the cave. The isotopic composition of cave suspended POM displayed lower $\delta^{13} \mathrm{C}$ and higher $\delta^{15} \mathrm{~N}$ values compared to outside (Table 2, Fig. 3). Higher $\delta^{15} \mathrm{~N}$ values could be attributed to the microbial degradation of organic matter (Chen et al. 2008), attested by a modification of its biochemical composition (Fichez 1991a). However, such a process could not explain the lower $\delta^{13} \mathrm{C}$ values as microbial degradation usually increase ${ }^{13} \mathrm{C}$ carbonates (Lehmann et al. 2002, Chen et al. 2008). Two non-exclusive hypotheses can be proposed to explain cave POM isotopic compositions. First, it could be due to passive import of terrestrial soil material low in ${ }^{13} \mathrm{C}$ carbonates percolating through the cracks and fissures of the limestone bedrock (Pohlman et al. 1997). Second, it could be the result of an increase in refractory material with low carbon signature due to the selective use of more labile material as observed during early diagenesis (Lehmann et al. 2002, Chen et al. 2008).

The analysis of SOM inside Jarre and 3PP Caves revealed similar variations of $\% \mathrm{C}$ and $\% \mathrm{~N}$ values that decreased from the entrance to the end of the cave (Table 2). These results accord with those of Fichez (1990, 1991b), who demonstrated a decrease in allochthonous organic inputs inside marine caves, connected to a decrease in benthic community richness and an increase in biochemical degradation of organic carbon, particularly evident in the darkest parts of caves. High \% $\mathrm{C}$ and $\% \mathrm{~N}$ and high $\mathrm{C}: \mathrm{N}$ values observed at cave entrances compared to outside, mid-cave, and cave ends (Table 2) reflect an accumulation of organic material (seagrass and macroalgal detritus) observed on cave floors just over the entrance sill. As observed for suspended POM, SOM isotopic compositions (increase in $\delta^{15} \mathrm{~N}$ and decrease in $\delta^{13} \mathrm{C}$ values) likely reflect preferential consumption of labile organic compounds by meiobenthos and microbes, and the accumulation of refractory compounds (Chen et al. 2008). The higher nitrogen composition of cave dwellers could also contribute to the increase of the nitrogen composition of SOM from inside caves through the accumulation of their dead bodies, mostly small crustaceans such as cope- 
pods and mysids, as they form large swarms continuously swimming above the sediment. Thus, supply of organic matter by POM and SOM to the cavedwelling organisms sharply decreases from the entrances to the ends of caves. To survive under these particularly oligotrophic conditions mobile organisms such as mysids must often migrate to other environments that provide more abundant and richer food resources.

\section{Mysids and the functioning of marine cave food webs}

Devoid of autochthonous photosynthetic primary production, marine caves rely exclusively on allochthonous organic material for their trophic functioning, either by passive advection of suspended POM or through active migrations of mobile organisms from the cave to the open marine environment and vice versa. Our results, along with those of Fichez (1990, 1991c), show that most suspended POM stays at the entrance of caves due to consumption by a dense population of filter feeders and rapid sedimentation resulting from weak flows and reduced mixing of water masses (Fichez 1991a,c, Palau et al. 1991, Garrabou \& Flos 1995). Thus, the most important carbon influx to caves resides in active migration by mobile organisms and habitat coupling between outside and inside of caves.

In some caves, fecal pellet production by dense populations of Hemimysis speluncola leads to high organic matter transfer from the productive outside photic zone (Coma et al. 1997). These authors estimate that mysid populations can account for 134 to $1400 \%$ of the POM baseline in marine caves. Our results, together with previously published works, suggest that 4 of the 5 mysid species analyzed $(H$. speluncola, $H$. margalefi, $H$. 1. mediterranea, and Siriella gracilipes) play active roles in carbon transfer to cave food webs, as their position relative to the cave varies daily. $H$. speluncola and $H$. margalefi contribute to enriching the darkest part of caves in organic matter, while $H$. 1 . mediterranea and $S$. gracilipes mainly transfer organic matter to the semidark parts of caves (Fig. 6). In contrast, Harmelinella mariannae seems to stay inside the darkest parts of caves to feed on the small, cave-dwelling crustaceans found there.

Mysid fecal pellets can constitute an important food resource for cave macrofaunal deposit feeders and meiofauna (Rossi \& Lardicci 2002). But mysids play another role in cave trophic webs, as they are consumed by various types of predators during their circadian migrations. Stomach content and stable isotope analyses performed in the present study indicated that cave-dwelling fishes such as Apogon imberbis and Thorogobius ephippiatus, at least in part, feed on mysids. It has also been shown that sciaphilic fishes entering caves, such as Anthias anthias, can actively prey on Hemimysis (Ribes et al. 1996). The high $\delta^{15} \mathrm{~N}$ values of adult $A$. imberbis $(9.6$ to $10.4 \%$ ) is congruent with previous studies $(9.8 \%$; Pinnegar \& Polunin 2000), suggesting a diet based on crustaceans and fishes, which was confirmed by stomach content analysis. A. imberbis and T. ephippiatus prey on mysids but also feed on other prey including benthic polychaetes. The high nitrogen signature of decapod shrimp suggests that they can also prey on cave-dwelling mysids, as observed for Palaemon xiphias (Guerao 1995). But mysids are also consumed by sessile invertebrates such as the deepsea carnivorous cladorhizid sponge Asbestopluma hypogea (Vacelet \& Duport 2004), exceptionally occurring in both Jarre and 3PP Caves (Bakran-Petricioli et al. 2007). Cerianthids and other cnidarians must also prey on mysids (Harmelin et al. 1985, Boero et al. 1991). The predation of mysids by sessile and mobile cave-dwelling predators emphasizes their role in energy transfer from the open waters to cave ecosystems.

Cave-dwelling mysids play a prominent role in the trophic webs of marine caves compensating for the oligotrophic nature of this environment in 2 ways: first by fecal pellet egestion and second as abundant prey for cave-dwelling carnivores (Fig. 6). Such a role is favored by the different migratory behaviors

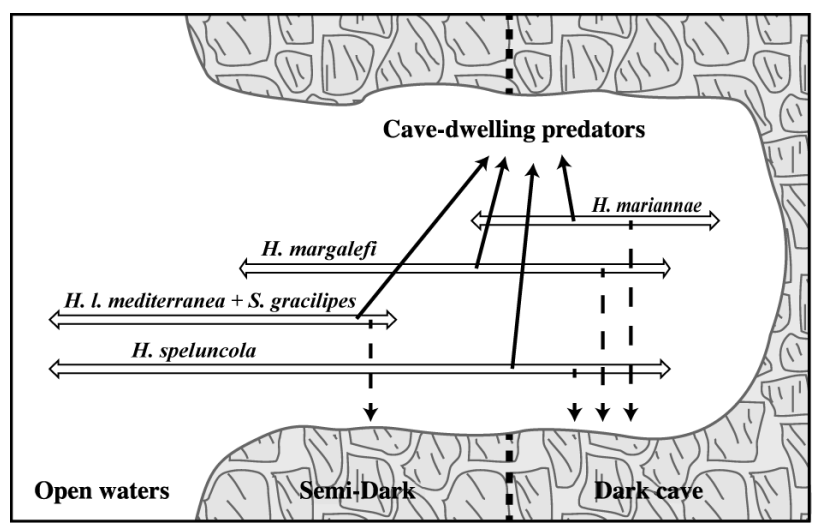

Fig. 6. Theoretical view of the organic matter flux in underwater marine caves mediated by the 5 most common cave mysid species in the NW Mediterranean Sea. Empty arrows indicate mysid distribution range in the cave, including circadian migrations; black arrows indicate predation on mysids by cave-dwelling carnivores; and dashed arrows represent fecal pellet production. Full species names in Fig. 4 
and by the food partitioning observed among the 5 mysid species studied here. A more detailed study on mysid feeding behavior is currently under way using a DNA-based analysis of gut contents (Blankenship \& Yayanos 2005), since mysids macerate their prey beyond recognition (Mauchline 1980, Lesutiene et al. 2007). A better understanding of the trophic functioning of marine caves will also allow the analysis of more faunal compartments involved, including sessile invertebrates, macro- and meiofauna, and small crustaceans that can constitute potential prey for some mysids and other cave-dwelling consumers.

Finally, the recent regional warming of the NW Mediterranean Sea (Lejeusne et al. 2010) has been shown to be responsible for a sharp decrease in abundance and distribution of one key species of mysid in the transfer of organic matter inside caves, Hemimysis speluncola (Chevaldonné \& Lejeusne 2003). This climate-related regional species shift must therefore have altered the functioning of at least some cave communities. Further investigations of these model systems may therefore shed some light on how climate change, and the removal of key species, may alter the functioning of poorly resilient ecosystems.

Acknowledgements. The authors thank F. Zuberer, B. De Ligondes, C. Marschal, G. Bleton, P. Rodriguez, P. Romans, and M. Lafont for assistance in SCUBA diving and sampling cave organisms. G. Guillou and M.-F. Fontaine provided helpful technical support to conduct stable isotope analyses. We also thank Pierre Cresson for providing data on the isotopic compositions of the Huveaune River. We are grateful to 3 anonymous reviewers for most valuable comments and improvements of the manuscript. C. Lejeusne is acknowledged for earlier trials on Hemimysis isotopic signatures.

\section{LITERATURE CITED}

Bakran-Petricioli T, Vacelet J, Zibrowius H, Petricioli D, Chevaldonné P, Rada T (2007) New data on the distribution of the 'deep-sea' sponges Asbestopluma hypogea and Oopsacas minuta in the Mediterranean Sea. Mar Ecol Evol Persp 28:10-23

Benzid D, De Jong L, Lejeusne C, Chevaldonné P, Moreau X (2006) Serotonin expression in the optic lobes of cavernicolous crustaceans during the light-dark transition phase: role of the lamina ganglionaris. J Exp Mar Biol Ecol 335:74-81

Blankenship LE, Yayanos AA (2005) Universal primers and PCR of gut contents to study marine invertebrate diets. Mol Ecol 14:891-899

Boero F, Cicogna F, Pessani D, Pronzato R (1991) In situ observations on contraction behavior and diel activity of Halcampoides purpurea var mediterranea (Cnidaria, Anthozoa) in a marine cave. Mar Ecol Pub Stn Zool Napoli 12:185-192

Boscarino BT, Rudstam LG, Eillenberger JL, O'Gorman R
(2009) Importance of light, temperature, zooplankton and fish in predicting the nighttime vertical distribution of Mysis diluviana. Aquat Biol 5:263-279

Buchheister A, Latour RJ (2010) Turnover and fractionation of carbon and nitrogen stable isotopes in tissues of a migratory coastal predator, summer flounder (Paralichthys dentatus). Can J Fish Aquat Sci 67:445-461

Bussotti S, Guidetti P (2009) Do Mediterranean fish assemblages associated with marine caves and rocky cliffs differ? Estuar Coast Shelf Sci 81:65-73

Carola M, Coma R, Riera T, Zabala M (1993) Fecal pellets collection as a method for assessing egesta of the marine cave-dwelling mysid Hemimysis speluncola. Sci Mar 57: 51-63

> Chen FR, Zhang L, Yang YQ, Zhang DR (2008) Chemical and isotopic alteration of organic matter during early diagenesis: evidence from the coastal area off-shore the Pearl River estuary, south China. J Mar Syst 74:372-380

Chevaldonné P, Lejeusne C (2003) Regional warminginduced species shift in north-west Mediterranean marine caves. Ecol Lett 6:371-379

Chevaldonné P, Sket B, Marschal C, Lejeusne C, Calado R (2008) Improvements to the 'Sket bottle': a simple manual device for sampling small crustaceans from marine caves and other cryptic habitats. J Crustac Biol 28: 185-188

Coma R, Carola M, Riera T, Zabala M (1997) Horizontal transfer of matter by a cave-dwelling mysid. Mar Ecol Pub Stn Zool Napoli 18:211-226

> Darnaude AM, Salen-Picard C, Polunin NVC, HarmelinVivien ML (2004) Trophodynamic linkage between river runoff and coastal fishery yield elucidated by stable isotope data in the Gulf of Lions (NW Mediterranean). Oecologia 138:325-332

Dauby PA (1995) A $\delta^{13} \mathrm{C}$ study of the feeding habits in four Mediterranean Leptomysis species (Crustacea, Mysidacea). Mar Ecol Pub Stn Zool Napoli 16:93-102

$>$ Deniro MJ, Epstein S (1978) Influence of diet on distribution of carbon isotopes in animals. Geochim Cosmochim Acta 42:495-506

- Fichez R (1990) Decrease in allochthonous organic inputs in dark submarine caves, connection with lowering in benthic community richness. Hydrobiologia 207:61-69

Fichez R (1991a) Benthic oxygen uptake and carbon cycling under aphotic and resource-limiting conditions in a submarine cave. Mar Biol 110:137-143

Fichez R (1991b) Composition and fate of organic matter in submarine cave sediments -implications for the biogeochemical cycle of organic carbon. Oceanol Acta 14: 369-377

Fichez R (1991c) Suspended particulate organic matter in a Mediterranean submarine cave. Mar Biol 108:167-174

Garrabou J, Flos J (1995) A simple diffusion-sedimentation model to explain planktonic gradients within a NW Mediterranean submarine cave. Mar Ecol Prog Ser 123: 273-280

- Gaudy R, Guérin JP (1979) Écophysiologie comparée des mysidacés Hemimysis speluncola Ledoyer (cavernicole) et Leptomysis lingvura G. O. Sars (non cavernicole). Action de la température sur la croissance en élevage. J Exp Mar Biol Ecol 38:101-119

Gorokhova E, Hansson S (1999) An experimental study on variations in stable carbon and nitrogen isotope fractionation during growth of Mysis mixta and Neomysis integer. Can J Fish Aquat Sci 56:2203-2210

> Guerao G (1995) Locomotor activity patterns and feedinghabits in the prawn Palaemon xiphias (Crustacea, 
Decapoda, Palaemonidae) in Alfacs Bay, Ebro Delta (northwest Mediterranean). Mar Biol 122:115-119

Harmelin JG (1994) Les peuplements de substrats durs circalittoraux. In: Bellan-Santini D, Lacaze J-C, Poizat C (eds) Les biocénoses marines et littorales de Méditerranée, synthèse, menaces et perspectives. Muséum National d'Histoire Naturelle, Paris, p 118-126

Harmelin JG (1997) Diversity of bryozoans in a Mediterranean sublittoral cave with bathyal-like conditions: role of dispersal processes and local factors. Mar Ecol Prog Ser 153:139-152

Harmelin JG, Vacelet J, Vasseur P (1985) Les grottes sousmarines obscures: un milieu extrême et un remarquable biotope refuge. Tethys 11:214-229

> Harmelin-Vivien M, Loizeau V, Mellon C, Beker B and others (2008) Comparison of $\mathrm{C}$ and $\mathrm{N}$ stable isotope ratios between surface particulate organic matter and microphytoplankton in the Gulf of Lions (NW Mediterranean). Cont Shelf Res 28:1911-1919

Harmelin-Vivien M, Dierking J, Banaru D, Fontaine MF, Arlhac D (2010) Seasonal variation in stable C and N isotope ratios of the Rhone River inputs to the Mediterranean Sea (2004-2005). Biogeochemistry 100:139-150

Hobson ES, Chess JR (1976) Trophic interactions among fishes and zooplankters near shore at Santa Catalina island, California. Fish Bull 74:567-598

Jumars PA (2007) Habitat coupling by mid-latitude, subtidal, marine mysids: import-subsidised omnivores. In: Oceanography and Marine Biology, Vol 45. CRC Press, Boca Raton, p 89-138

Kurle CM, Sinclair EH, Edwards AE, Gudmundson CJ (2011) Temporal and spatial variation in the $\delta^{15} \mathrm{~N}$ and $\delta^{13} \mathrm{C}$ values of fish and squid from Alaskan waters. Mar Biol (in press) doi:10.1007/s00227-011-1741-4

Ledoyer M (1989) Les mysidacés (Crustacea) des grottes sous-marines obscures de Méditerranée nord-occidentale et du proche Atlantique (Portugal et Madère). Mar Nature 2:39-62

Lehmann MF, Bernasconi SM, Barbieri A, McKenzie JA (2002) Preservation of organic matter and alteration of its carbon and nitrogen isotope composition during simulated and in situ early sedimentary diagenesis. Geochim Cosmochim Acta 66:3573-3584

Lehtiniemi M, Nordström H (2008) Feeding differences among common littoral mysids, Neomysis integer, Praunus flexuosus and $P$. inermis. Hydrobiologia 614:309-320

Lehtiniemi M, Kiljunen M, Jones RI (2009) Winter food utilisation by sympatric mysids in the Baltic Sea, studied by combined gut content and stable isotope analyses. Mar Biol 156:619-628

Lejeusne C, Chevaldonné P (2005) Population structure and life history of Hemimysis margalefi (Crustacea: Mysidacea), a 'thermophilic' cave-dwelling species benefiting from the warming of the NW Mediterranean. Mar Ecol Prog Ser 287:189-199

Lejeusne C, Chevaldonné P, Pergent-Martini C, Boudouresque $C F$, Perez $T$ (2010) Climate change effects on a miniature ocean: the highly diverse, highly impacted Mediterranean Sea. Trends Ecol Evol 25:250-260

Lesutiene J, Gorokhova E, Gasiunaite ZR, Razinkovas A (2007) Isotopic evidence for zooplankton as an important food source for the mysid Paramysis lacustris in the Curonian Lagoon, the South-Eastern Baltic Sea. Estuar Coast Shelf Sci 73:73-80

Macquart-Moulin C, Passelaigue F (1982) Mouvements nychtéméraux d'Hemimysis speluncola Ledoyer, espèce cavernicole, et de Leptomysis lingvura G.O. Sars, espèce non-cavernicole (Crustacea, Mysidacea). Tethys 10: 221-228

Mauchline J (1980) The biology of mysids and euphausiids. Blaxter JHS, Russell FS, Yonge M (eds) Advances in marine biology, Vol 18., Academic Press, London

Moscatello S, Belmonte G (2007) The plankton of a shallow submarine cave ('Grotta di Ciolo', Salento Peninsula, SE Italy). Mar Ecol Evol Persp 28:47-59

Palau M, Cornet C, Riera T, Zabala M (1991) Planktonic gradients along Mediterranean sea cave. Oecol Aquat 10: 299-316

Passelaigue F (1989) Les migrations journalières du Mysidacé marin cavernicole Hemimysis speluncola. Comparaison avec les migrations verticales du plancton. Thèse d'Etat, Université d'Aix-Marseille II

Passelaigue F, Bourdillon A (1986) Distribution and circadian migrations of the cavernicolous mysid Hemimysis speluncola Ledoyer. Stygologia 2:112-118

Phillips DL, Gregg JW (2003) Source partitioning using stable isotopes: coping with too many sources. Oecologia 136:261-269

Pinnegar JK, Polunin NVC (1999) Differential fractionation of $\delta^{13} \mathrm{C}$ and $\delta^{15} \mathrm{~N}$ among fish tissues: implications for the study of trophic interactions. Funct Ecol 13:225-231

> Pinnegar JK, Polunin NVC (2000) Contributions of stableisotope data to elucidating food webs of Mediterranean rocky littoral fishes. Oecologia 122:399-409

Pohlman JW, Iliffe TM, Cifuentes LA (1997) A stable isotope study of organic cycling and the ecology of an anchialine cave ecosystem. Mar Ecol Prog Ser 155:17-27

Post DM (2002) Using stable isotopes to estimate trophic position: models, methods, and assumptions. Ecology 83:703-718

Ribes M, Coma R, Zabala M, Gili JM (1996) Small-scale spatial heterogeneity and seasonal variation in a population of a cave-dwelling Mediterranean mysid. J Plankton Res 18:659-671

Riera T, Zabala M, Peñuelas J (1991) Mysids from a submarine cave emerge each night to feed. Sci Mar 55:605-609

Rossi F, Lardicci C (2002) Role of the nutritive value of sediment in regulating population dynamics of the depositfeeding polychaete Streblospio shrubsolii. Mar Biol 140: 1129-1138

Takahashi K (2004) Feeding ecology of mysids in freshwater and coastal marine habitats: a review. Bull Plankton Soc Japan 51:46-72

Tattersall WM, Tattersall OS (1951) The British Mysidacea, Vol 136. Ray Society, London

Topçu NE, Pérez T, Grégori G, Harmelin-Vivien M (2010) In situ investigation of Spongia officinalis (Demospongiae) particle feeding: coupling flow cytometry and stable isotope analysis. J Exp Mar Biol Ecol 389:61-69

Vacelet J, Duport E (2004) Prey capture and digestion in the carnivorous sponge Asbestopluma hypogea (Porifera: Demospongiae). Zoomorphology 123:179-190

Winkler G, Martineau C, Dodson JJ, Vincent WF, Johnson LE (2007) Trophic dynamics of two sympatric mysid species in an estuarine transition zone. Mar Ecol Prog Ser 332:171-187

Wittmann KJ (2001) Centennial changes in the near-shore mysid fauna of the Gulf of Naples (Mediterranean Sea), with description of Heteromysis riedli sp. n. (Crustacea, Mysidacea). PSZNI: Mar Ecol 22:85-109

Submitted: June 17, 2011; Accepted: August 16, 2011

Proofs received from author(s): October 19, 2011 